\title{
The pioneer contribution of Luiz Marcellino de Oliveira to experimental analysis of behavior and psychobiological investigation in Brazil
}

\author{
Elenice A. de Moraes Ferrari \\ Universidade de Campinas, São Paulo, Brazil
}

\begin{abstract}
Luiz Marcellino de Oliveira (1939-2008) had an influential participation in almost every moment of the history of the Department of Psychology and Education, FFCLRP, as well as at different moments of the history of the Brazilian Psychology. This paper examines issues related to his pioneer work as a teacher of experimental analysis of behavior and as a psychobiological investigator in Brazil. Emphasis is given to his dedication to the development of science and to the consolidation of a scientific approach to Psychology in Brazil at the level of teaching and of experimental investigation. He contributed with investigations on the effects of drugs and malnourishment on behavior and brain development, conducting experimental analysis of behavior and neurochemical and electrophysiological analysis of the nervous system of the malnourished organism, as well as putting emphasis on environmental stimulation as a valuable intervention. Both as a teacher and as a researcher he exerted a prime influence on numerous professionals and members of the academic community that during more than forty years had the privilege of benefiting from his friendship and knowledge. Key words: Luiz Marcellino de Oliveira; experimental analysis of behavior; psychobiology; malnutrition; environmental stimulation.
\end{abstract}

Received 22 October 2008; received in revised form 27 December 2008; accepted 27 December 2008. Available online 29 December 2008.

Luiz Marcellino de Oliveira (1939 - 2008) graduated in Psychology in 1966, received the degree of Master in Science in 1971 and the Doctoral (PhD) degree in 1973, all degrees were obtained at the University of São Paulo. Post-doctoral studies were conducted at the University of Cornell (1977-1978) and at the University of Chile (1989). Throughout his academic career, Dr. Luiz de Oliveira had a high standard professional value that was attested by his dedication to teaching, to research activities and to the formation of young researchers. He had active and influential participation in almost every moment of the history of the Department of Psychology and Education, FFCLRP. Additionally, he participated in scientific committees at CNPq and CAPES and had an important, and sometimes essential, involvement with the consolidation of the former Sociedade de Psicologia de Ribeirão Preto/ Sociedade Brasileira de Psicologia, which he presided many times as well as

Elenice A. de Moraes Ferrari, Departamento de Fisiologia e Biofísica, Instituto de Biologia, UNICAMP. Correspondence regarding this article should be directed to Elenice A. de Moraes Ferrari - Departamento de Fisiologia e Biofísica, Instituto de Biologia, UNICAMP, Cidade Universitária Prof. Zeferino Vaz, 13083-970, Campinas, SP, Brasil; Fone: 55-19 35216207 FAX: 55-19 3521 6185; e-mail: elenice@unicamp.br organized annual scientific meetings of its members (1974-1975; 1975-1976; 1978-1979; 1981-1982; 19981999). We can say that he spent a life time of dedication to the development of science and, particularly, to the consolidation of a scientific approach to Psychology either at the level of teaching, experimental investigation, clinical applications and legislation on the curriculum of Psychology courses.

The strength and importance of his work is such that in many ways, and for many people, thinking about Ribeirão Preto and about the Psychology undergraduate course at the Faculty of Philosophy, Sciences and Letters (FFCLRP) brings together feelings and memories that are unequivocally linked to Luiz de Oliveira. The memory of his presence is somehow irreversibly linked to the buildings, to the sidewalks, to the cafeteria, to the classrooms and to laboratories where science is nurtured by selected groups of researchers and students that are part of a well known and respected scientific community. Indeed, his dynamic, vigorous, friendly and, we may say, revolutionary action has been part of the history of the undergraduate course of Psychology at FFCLRP since its very first years.

At the time he arrived to Ribeirão Preto, he brought with him a previous personal history plenty of educational, scientific and political experiences 


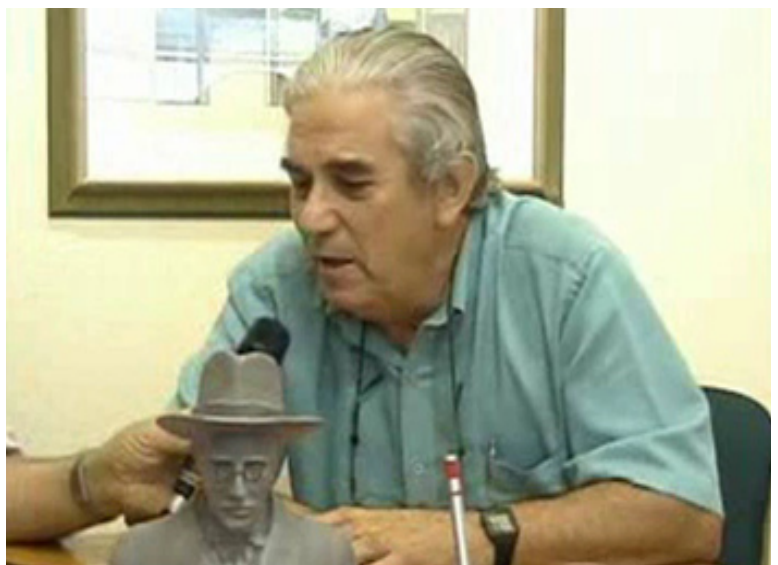

Figure 1. Luiz Marcellino during the interview for the RP9 TV in the Program "Cientistas de Ribeirão Preto", 2007.

developed during the years spent at the University of Brasília from 1964 to 1966 . This period of time is denoted as one of hard days and nights under the dictatorial military government that was imposed to the Brazilian people as a reaction to a supposed menace of a leftist political influence that could lead to a communist regimen. This authoritarian government was announced as transitory, but had a longer duration than predicted, which affected tragically human rights and free expression of all forms of thinking and social organization. One of the institutional victims of such political state of freedom restriction was the collapse of the newly born University of Brasília, when in 1965 there was the resignation of the great majority of teachers and researchers (Todorov, 1997). This manifest against abusive political interference at the university had a very high impact as an abrupt interruption of the educational and scientific strategies designed for the Psychology course at that university as well as of the personal careers, life and family plans of may researchers, teachers and students. The unpredicted institutional changes brought Luiz de Oliveira to Ribeirão Preto, carrying a rich history of experiences that undoubtedly was the hallmark of his long and intense involvement with the scientific community in that university campus. There he completed his undergraduate studies in Psychology.

As a young teacher assistant, in 1966, he organized and coordinated the Laboratory of Learning that provided situations and contingencies for the learning of psychology as a scientific analysis of behavior. $\mathrm{He}$ was one of the pioneers in teaching experimental analysis of behavior as a formal discipline of the undergraduate curriculum in Psychology at the campus. The basic principles of behavior were taught through

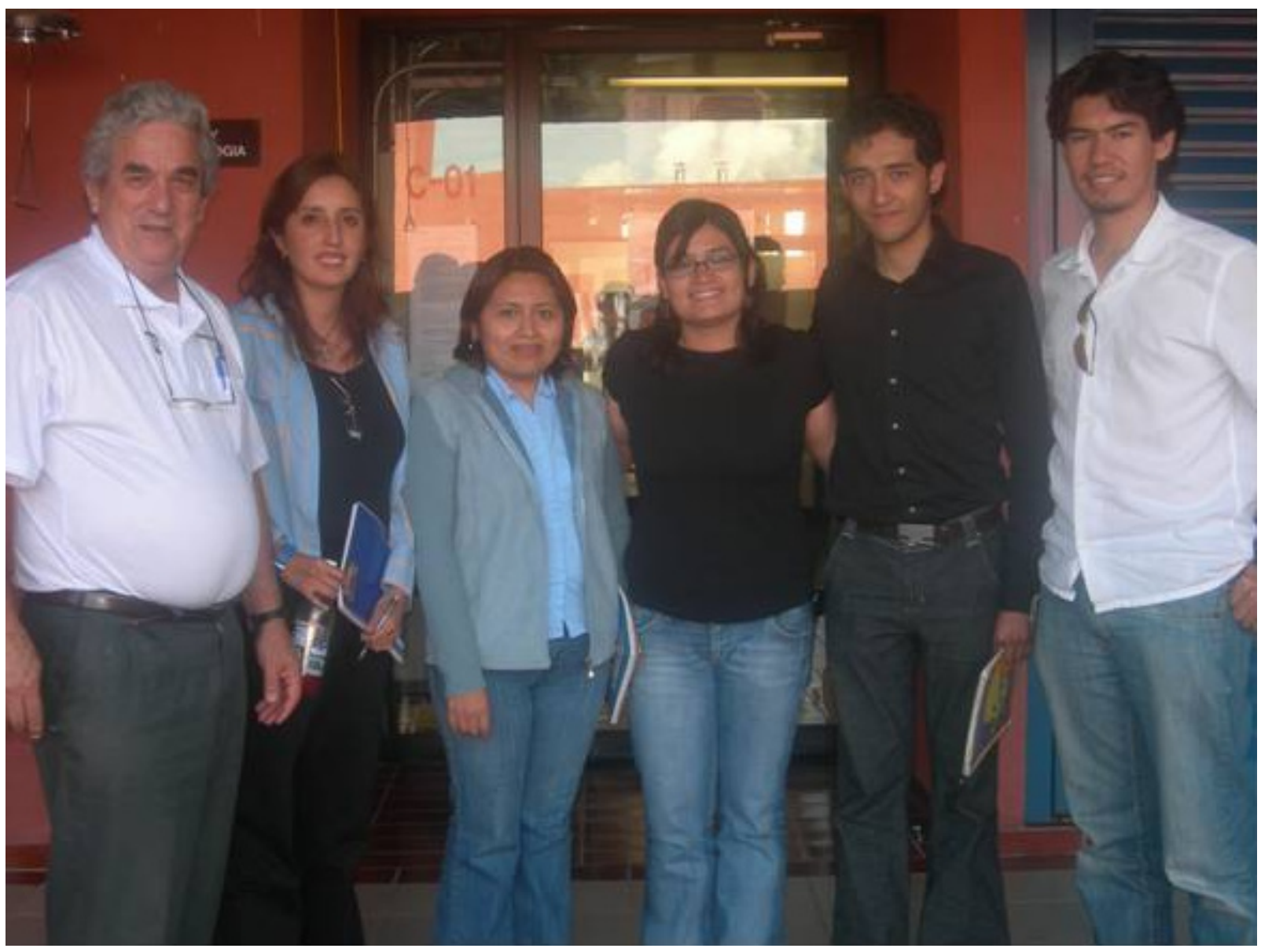

Figure 2. Picture taken with researchers from the Institute of Neurobiology, Universidad Autonoma de Mexico, 2006. 
programmed courses, using a teaching technology with the individualized and programmed instructional system developed by Fred S. Keller, Carolina M. Bori, Rodolfo Azzi and Gilmour Sherman (Keller, 1968; Keller, 1996), which was previously applied at the University of Brasilia. Emphasis was given on the individual progress toward learning and on the reinforcement value of knowledge acquisition per se (Keller, 1968; Matos, 1996). The learning objectives were carefully defined and they were attained gradually, along a sequence of steps that were meticulously programmed. Each step provided opportunities for the collection of experimental data - and this required a teaching laboratory with skinner boxes, counters, cumulative records-, their analysis, interpretation and integration within behavioral principles, learning concepts and clinical applications as well. Each student had one complete series of experiments to be conducted with one laboratory rat that was given at the beginning of the discipline. A new behavioral repertoire was shaped, installed and maintained both in the rat and in every student that constituted a complex repertoire indicative of conceptual and experimental skills. Since the development of individualized and programmed instruction required effective contingencies of reinforcement in order to strength the probability of the desired behaviors, professor Luiz de Oliveira recruited and intensively trained and dedicatedly prepared a team of undergraduate monitors to accompany the evaluation of the students's progression across the programmed steps of learning. Such endeavor required effort, dedication and competence to which he added the enthusiasm and enjoyment that characterize the pioneer work of people who follow their dreams. Undoubtedly his dedication was a prime influence for many Brazilian professionals that are nowadays productively working in basic and clinical research or at different institutions around our country - state, federal or private universities.

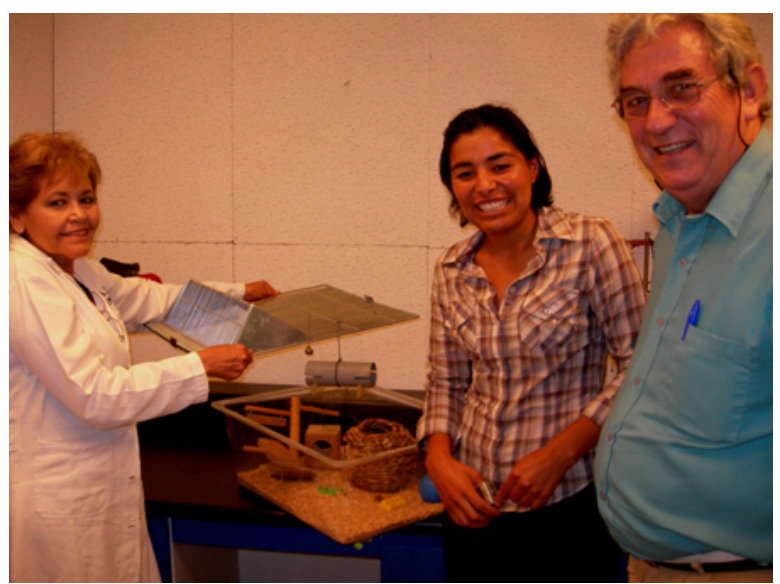

Figure 4. Luiz Marcellino with students during experimental practices in the laboratory, 2006.

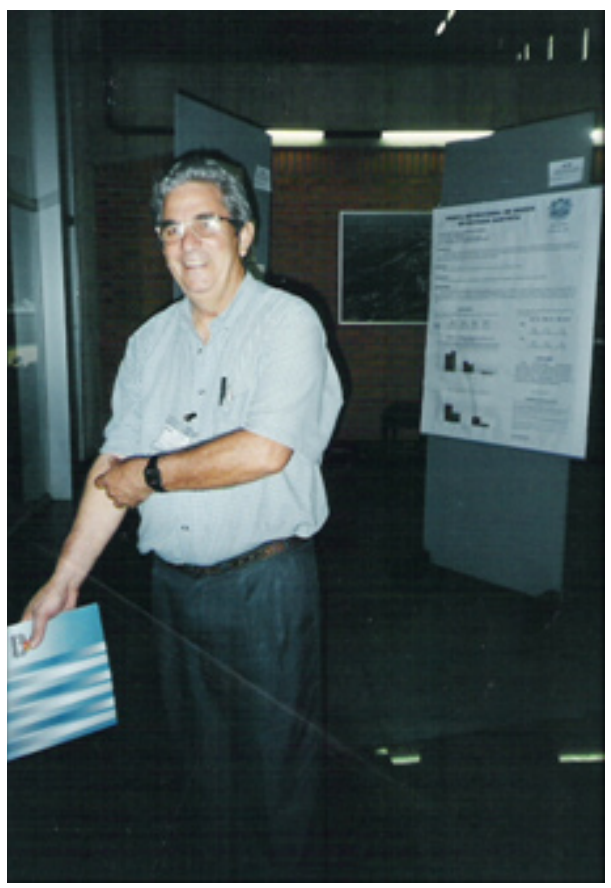

Figure 3. Luiz Marcellino during the Reunião Anual da Sociedade Brasileira para o Progresso da Ciência, São Paulo, 1996.

Actually, since the early years of his academic career Luiz de Oliveira had an elevated commitment to good quality teaching and to the scientific formation of the undergraduate student of Psychology. During the period of 1968 to 1972, he dedicated efforts toward the recruitment of researchers and teachers for the school board of the Department of Psychology and EducationFFCLRP, which resulted in the admission of new faculty members, including Ana Maria Musiello, Elza M. Stella, Lino de Macedo, Maria Tereza Araújo e Silva and myself as well. These were times of intensive work, highly stimulating encounters and long-duration meetings at the department that continued at the dinning table of restaurants. The enthusiastic conversations always had Luiz de Oliveira as a central figure talking over the design of new curricular disciplines, experimental procedures, discussion of scientific papers as well as university and governmental politics.

It is worth to say that the birth and development of the advanced research group in Psychobiology at FFCLRP had, since the early stages, Luiz de Oliveira's contribution. Again, as a pioneer he was one of the first Brazilian behavior analysts interested in investigating how drugs affected the control of behavior by reinforcement schedules. The geographical proximity and the vigorous scientific interactions with the pharmacologists and physiologists of the Faculty of Medicine of the University of São Paulo at Ribeirão Preto (FMRP-USP) favored a fertile interchange both in teaching and scientific investigations. Under the supervision of Frederico Guilherme Graeff he worked on his doctoral thesis entitled 'Effects of amphetamine 
and apomorphine in the behavior under fixed-interval (IF)' (De Oliveira, 1973; De Oliveira \& Graeff, 1972; Graeff \& De Oliveira, 1975).

That work may have stimulated inquiries on drugs as a class of variables that could alter the reinforcement value of the stimuli thus providing a powerful tool for investigation of how biological variables and contingencies of reinforcement were related. Moreover, the relationships between the effects of drug administration on an organism and reinforcement variables pointed to psychobiology as an interesting and important scientific field that could be stimulated and developed at FFCLRP. Later, he began a new line of research that was focused on the effects of malnutrition on behavior development and learning (Cambraia, Vannucchi \& De Oliveira, 1997; De Oliveira, 1983; De Oliveira, Costa \& Vannucchi., 1995; Santucci, Daud, Almeida \& De Oliveira, 1994). The analysis of the relationships between these classes of variables conducted him to extend the focus of investigation to include interventions that used environmental stimulation as well as aspects of the eletrophysiological and neurochemical alterations of the nervous system (Lima, De Oliveira, Lachat, Nicola \& Almeida, 1993; Lima, De Oliveira \& Almeida, 1999; Rocinholi, De Oliveira \& Colafemina, 2001a; Rocinholi De Oliveira \& Colafemina, 2001b). The results obtained in experiments conducted with rodents stimulated his interest in studies using behavioral intervention with undernourished children.

Luiz de Oliveira, together with Frederico Guilherme Graeff, João Cláudio Todorov and Isaías Pessotti, was one of the organizers of the Laboratory of Operant Behavior and Drugs, a research laboratory that involved the joint action of researchers from the Psychology and from the Medical school. It may be considered the multidisciplinary laboratory that was the embryo of the present psychobiology sector as well as of the graduate course on Psychobiology at the Department of Psychology and Education -FFCLRPUSP. This laboratory was the place of many scientific interactions among behavioral analysts, psycopharmacologists, neurophysiologists, philosophers and undergraduate students, having offered, as well, the conditions for the conduction of several scientific investigations, in which the results originated doctoral and master theses, and were useful for the scientific initiation of young graduate students.

Finally, it is worth to say that Professor Luiz Marcellino de Oliveira had many personal values and characteristics that qualified him as a unique human being who lived with enthusiasm, dignity, sense of humor, companionship and respect for people of different professions and social classes. He was always interested and attentive to new ideas, new projects and plans. Besides his scientific legacy, he had unforgettable personal qualifications that will certainly be remembered and honored by many people, particularly the numerous members of the academic community that during more than forty years had the privilege of benefiting from his company, friendship and knowledge.

\section{References}

Cambraia, R. P. B. , Vannucchi, H. , De Oliveira, L. M. (1997). Food intake and weight of lactating rats, maintained on different protein-calorie. Brazilian Journal of Medical and Biological Research, 30, 985-988.

De Oliveira, L. M., Graeff, F. G. (1972). Comparison between the effects of amphetamine and apomorpine on operant behavior. European Journal of Pharmacology, 18, 159-165.

De Oliveira, L. M.. (1985). Malnutrition and environment: Interaction effects upon animal behavior. Revista Chilena de Nutrición, 13, 99-108.

De Oliveira, L. M., Costa, T. M. B., Vannucchi, H. (1995). Effects of zinc deficiency induced before and during pregnancy on the survival of female rats and their pups. Brazilian Journal of Medical and Biological Research, 28, 569-574.

Graeff, F. G. , De Oliveira, L. M. (1975). Influence of response topography on the effects of apomorphine on operant behavior of pigeons. Psychopharmacologia, 41, 127-132.

Keller, F.S. (1968). Good-bye, teacher... Journal of Applied Behavior Analysis, 1, 79-89.

Keller, F.S. (1996). Report on the Brasilia Plan. Psicologia: Teoria \&Pesquisa, 12, 193-197.

Lima, J. G., De Oliveira, L. M., Lachat, J. J., Nicola, D. C. P., Almeida, S. S. (1993). Comparison of the effects of lab chow and casein diets based on body and brain development of rats. Brazilian Journal of Medical and Biological Research, 26, 1069-1076.

Lima, J. G., De Oliveira, L. M., Almeida, S. S. (1999). Effects of early concurrent protein malnutrition and environmental stimulation on the central nervous system and behavior. Nutritional Neuroscience, $1,439-448$.

Matos, M. A. (1996). Contingências para a análise comportamental no Brasil: Fred S. Keller. Psicologia: Teoria \&Pesquisa, 12, 107-111.

Rocinholi, L. F., De Oliveira, L. M., Colafemina, J. F. (2001a). Malnutrition and environmental stimulation in rats: Interpeak intervals of the brainstem auditory evoked potentials. Nutritional Neuroscience, 4, 189-198.

Rocinholi, L. F., De Oliveira, L. M., Colafemina, J. F. (2001b). Malnutrition and environmental stimulation in rats: Wave Latencies of the brainstem auditory evoked potentials. Nutritional Neuroscience, 4, 199-212.

Santucci, L. B., Daud, M. M., Almeida, S. S., De Oliveira, L.M. (1994). Effects of early protein malnutrition and environmental stimulation upon the reactivity to diazepam in two animal models of anxiety. Pharmacology Biochemistry and Behavior, 49, 393-398.

Todorov, M. S. R. (1997). A Psicologia na Universidade de Brasilia de 1963, criação do primeiro departamento, até 1986 quando foi criado o Instituto de Psicologia. Brasília: CEDOC- UnB. 